\title{
An Analysis of the Complete Genome Sequence and Subgenomic RNAs Reveals Unique Features of the Ampelovirus, Grapevine leafroll-associated virus 1
}

\author{
Bhanu Priya Donda, Sridhar Jarugula, and Rayapati A. Naidu ${ }^{\dagger}$
}

Department of Plant Pathology, Washington State University, Irrigated Agriculture Research and Extension Center, Prosser, WA 99350. Current address of first author: Sunburst Plant Disease Clinic Inc., Turlock, CA 95380.

Accepted for publication 3 May 2017.

\begin{abstract}
Despite being the first closterovirus documented in grapevines (Vitis sp.), the molecular biology of Grapevine leafroll-associated virus 1 (GLRaV-1, genus Ampelovirus, family Closteroviridae) is still in its infancy. In this study, the complete genome sequence of two GLRaV-1 isolates was determined to be 18,731 (isolate WA-CH) and 18,946 (isolate WA-PN) nucleotides (nt). The genome of WA-CH and WA-PN isolates encodes nine putative open reading frames (ORFs) and the arrangement of these ORFs in both isolates was similar to that of Australian and Canadian isolates. In addition to two divergent copies of the coat protein (CP), the genome of GLRaV-1 isolates contain CP-homologous domain in four genes, making the virus unique among Closteroviridae members. The 5' and $3^{\prime}$ nontranslated regions (NTRs) of WA-CH and WA-PN isolates showed differences in size and sequence composition, with 5' NTR having

variable number of $\sim 65$-nt-long repeats. Using the $5^{\prime}$ NTR sequences, a reverse transcription-polymerase chain reaction and restriction fragment length polymorphism method was developed to distinguish GLRaV-1 variants in vineyards. Northern analysis of total RNA from GLRaV-1infected grapevine samples revealed three subgenomic RNAs (sgRNAs), corresponding tentatively to $\mathrm{CP}, \mathrm{p} 21$, and p24 ORFs, present at higher levels, with p24 sgRNA observed at relatively higher abundance than the other two sgRNAs. The $5^{\prime}$ terminus of sgRNAs corresponding to CP, CPd1, $\mathrm{CPd} 2$, p21, and p24 were mapped to the virus genome and the leader sequence for these five sgRNAs determined to be $68,27,15,49$, and $18 \mathrm{nt}$, respectively. Taken together, this study provided a foundation for further elucidation of the comparative molecular biology of closteroviruses infecting grapevines.
\end{abstract}

Among the several virus diseases reported in grapevines (Vitis sp.), grapevine leafroll disease (GLD) continues to be the most economically important for grapes across viticultural regions worldwide (Martelli 2014; Naidu et al. 2014). Five distinct viral species, designated as Grapevine leafroll-associated virus 1, 2, 3, 4, and 7 (GLRaV-1, -2, -3, -4, and -7), have been documented from grapevines showing GLD symptoms or found to be associated with the disease (Martelli et al. 2012). Among them, GLRaV-1, -3, and -4 were assigned to the genus Ampelovirus, GLRaV-2 to the genus Closterovirus and GLRaV-7 to the genus Velarivirus in the family Closteroviridae (Martelli et al. 2012). The other previously described GLRaVs (GLRaV-5, -6, -9, -Pr, -De, and -Car) were reassigned as strains of GLRaV-4 (Martelli et al. 2012). Grapevineinfecting ampeloviruses were further divided into two subgroups with GLRaV-1 and GLRaV-3 having large genome size separated under subgroup I from GLRaV-4 and its strains with relatively small genome size included in subgroup II (Maliogka et al. 2008; Martelli et al. 2012). GLRaV-13, a distinct closterovirus recently reported from Japan, showed relatively close phylogenetic alignment with GLRaV-1 and -3 in the genus Ampelovirus (Ito and Nakaune 2016).

GLRaVs are disseminated mainly via clonal propagation of plant material. However, only ampeloviruses GLRaV-1, -3 , and -4 and its

†Corresponding author: R. A. Naidu; E-mail address: naidu.rayapati@wsu.edu

First and second authors contributed equally.

The GenBank accession numbers for the GLRaV-1 sequences reported in this article are KU674796 and KU674797.

*The $e$-Xtra logo stands for "electronic extra" and indicates that one supplementary table is published online.

(C) 2017 The American Phytopathological Society strains are known to be transmitted by species of mealybugs (Pseudococcidae) and scale insects (Coccidae) in a semi-persistent manner (Le Maguet et al. 2012; Tsai et al. 2010). In contrast, insect vectors for GLRaV-2 and GLRaV-7 are currently unknown (Al Rwahnih et al. 2012; Jelkmann et al. 2012). Although GLRaVs were implicated as causal agents of GLD due to their consistent presence in symptomatic grapevines, some strains of GLRaV-2 and GLRaV-7 were reported to cause asymptomatic infections with no apparent leafroll disease symptoms (Al Rwahnih et al. 2012; Alkowni et al. 2011; Bertazzon et al. 2010; Jelkmann et al. 2012; Poojari et al. 2013).

GLRaV-1 is considered as the second most widely distributed ampelovirus, after GLRaV-3, across grapevine-growing regions (Habili et al. 2007; Naidu 2017). Similar to other GLRaVs, the flexuous, filamentous virions of GLRaV-1 were localized in phloem-associated cells of the grapevine vascular system (Esteves et al. 2013; Seddas et al. 2000). The virions are presumed to have a unique "rattlesnake-like" architecture (Agranovsky et al. 1995) with particles composed of several viral-encoded proteins, as reported for other monopartite closteroviruses (Peremyslov et al. 2004; Satyanarayana et al. 2004). Although complete genome sequence for GLRaV-2, -3 , -4 and its strains, and -7 has been determined, only incomplete genome sequence is available for GLRaV-1 from Australia (Fazeli and Rezaian 2000; AF195822) and Canada (NC_016509). An analysis of the partial genome sequence revealed that both isolates encode nine putative open reading frames (ORFs) (Fig. 1A). The ORF 1 encodes two replication-associated proteins that constitutes the 'replication gene block' (RGB), analogous to other monopartite members of the family Closteroviridae (Dolja et al. 2006). The remaining eight ORFs are located downstream of the RGB in the $3^{\prime}$ portion of the virus genome. Organization of the first five of these eight ORFs, designated consecutively from $5^{\prime}$ to $3^{\prime}$ end of the virus genome as $\mathrm{p} 7$, heatshock protein 70 homolog (HSP70h), p55, coat protein (CP) and the 
first divergent copy of the $\mathrm{CP}(\mathrm{CPd} 1)$, comprise the quintuple gene block (QGB), similar to other monopartite closteroviruses (Dolja et al. 2006). Downstream of the QGB are three ORFs, designated sequentially as CPd2, p21 and p24 that are unique to GLRaV-1. Unlike other monopartite closteroviruses, including GLRaV-2, -3, -4, and $-7, \mathrm{GLRaV}-1$ encodes two divergent copies of the CP, CPd1, and CPd2. Studies have also shown that GLRaV-1 can occur as genetically distinct variants, with $\mathrm{CPd} 2$ being more divergent compared to other genes (Alabi et al. 2011; Fan et al. 2015; Kominek et al. 2005; Little et al. 2001).

Despite being the first closterovirus reported from grapevines, limited progress has been made in understanding the molecular biology of GLRaV-1 (Fazeli and Rezaian 2000; Habili et al. 2007; Naidu 2017). In this study, we determined the complete genome sequence of two GLRaV-1 isolates from Washington vineyards. In addition, experiments were conducted to reveal the expression of 3 '-coterminal subgenomic RNAs (sgRNAs) isolated from GLRaV1 -infected grapevines and determine the size of leader sequence for individual sgRNAs. The results provided a foundation for further elucidation of the molecular biology of GLRaV-1.

\section{MATERIALS AND METHODS}

Virus source. GLRaV-1 isolates used in this study were obtained from four wine grape (V. vinifera) cultivars (Chardonnay, Pinot noir, Cabernet Sauvignon, and Sauvignon Blanc) planted in commercial vineyards. Total RNA was extracted from cambial scrapings of mature canes from virus-infected vines using Sigma
Spectrum Plant Total RNA Kit (Sigma-Aldrich, St. Louis, MO), according to the manufacturer's instructions. The double-stranded (ds) RNA was isolated essentially as described by Jarugula et al. (2010) and Valverde et al. (1990). The integrity of total RNA and dsRNA preparations was verified by resolving in $0.8 \%$ agarose gels pre-stained with GelRed and visualizing under UV light using a transilluminator (Bio-Rad Universal Hood, Bio-Rad Laboratories).

cDNA synthesis, RT-PCR, cloning, and sequencing. The denatured dsRNA preparations were used as a template for cDNA synthesis using Superscript III reverse transcriptase (Thermo Fisher Scientific, Grand Island, NY), according to the manufacturer's instructions. Initially, primers to amplify the genome were designed based on GLRaV-1 sequences available in GenBank (NC_016509 and AF195822). Primer sequences subsequently used in this study and their co-ordinates with respect to the genome of GLRaV-1 WA-CH isolate (KU674796) are listed in the Supplementary Table S1. RT-PCR amplifications were performed with high-fidelity PrimeSTAR GXL DNA polymerase (Takara Bio Inc., Japan) as per the manufacturer's instructions. The amplicons were gel purified (GeneClean III Kit, MP Biomedicals, Santa Ana, CA), dA-tailed using Taq DNA polymerase (Roche, Mannheim, Germany), cloned into pCR-XL-TOPO vector (Thermo Fisher Scientific) and transformed into chemically competent Escherichia coli cells (Thermo Fisher Scientific), according to the manufacturer's instructions. Recombinant plasmid DNA from three independent colonies per amplicon was sequenced in both orientations (Retrogen, Inc., San Diego, CA). Additional clones were sequenced as needed to resolve sequence ambiguities between clones specific to each amplicon.
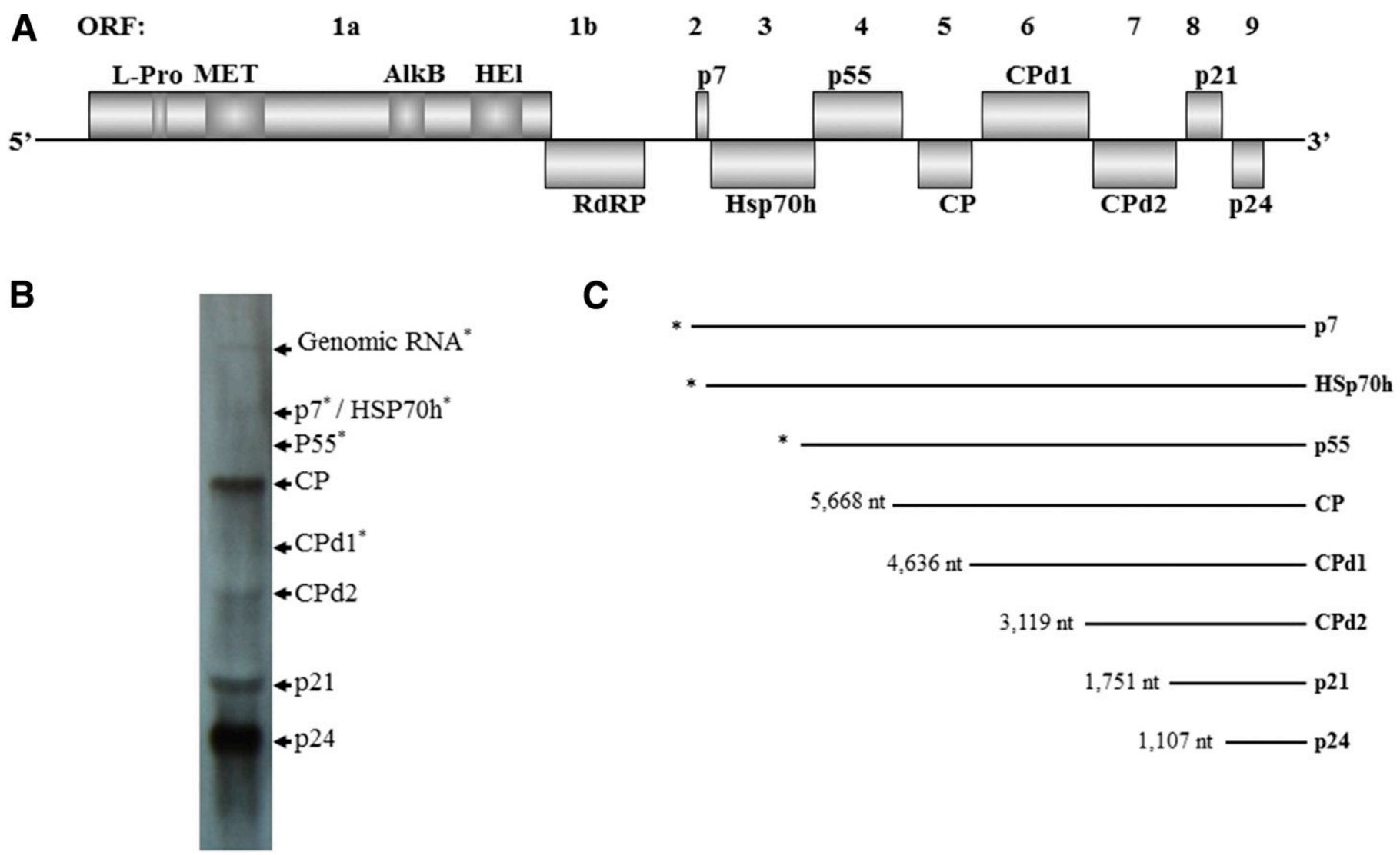

Fig. 1. A, Schematic diagram showing the genome organization of Grapevine leafroll-associated virus 1 (GLRaV-1) WA-CH isolate (KU674796). The open reading frames (ORFs) encoded by the virus are numbered 1 to 9 above the diagram and shown as boxes with associated protein designations following the convention used for closteroviruses (Dolja et al. 2006). L-Pro, leader proteinase; AlkB, an Alkylation B domain; MET, HEL, and RdRp, methyl transferase, RNA helicase, and RNA-dependent RNA polymerase domains, respectively; p7, a 7-kDa protein; HSP70h, a HSP70-homologue; p55, a 55-kDa protein; CP, the capsid protein $(\mathrm{CP})$; CPd1 and CPd2, the two divergent copies of the CP; and p21 and p24 are the 21- and 24-kDa proteins, respectively. B, Northern blot analysis of total RNA extracted from grapevine infected with GLRaV-1 showing the differential expression of 3'-coterminal sgRNAs. The locations of the sgRNAs are indicated by arrows on the right. The putative positions of the sgRNAs for CPd1, p55, HSP70h, and p7 and genomic RNA are shown with an asterisk. C, Schematic representation of the sizes of 3 '-coterminal sgRNAs. The sizes of CP, CPd1, CPd2, p21, and p24 sgRNAs (shown on left) are determined using the sequence of WA-CH isolate. The size of sgRNAs for p55, HSP70h, and p7 (shown with an asterisk) are not determined in this study. 
Determination of the $5^{\prime}$ and $3^{\prime}$ terminal sequences. The $5^{\prime}$ terminal sequence of GLRaV-1 was determined by rapid amplification of cDNA ends using a commercial 5'RACE system (version 2.0; Thermo Fisher Scientific), according to the manufacturer's instructions. First-strand cDNA was synthesized from dsRNA using the primer 5'-OP. A homopolymeric dC tail was added to the $3^{\prime}$ termini of purified cDNA using terminal deoxynucleotidyl transferase (Thermo Fisher Scientific). The dC-tailed cDNA was subsequently used in PCR to amplify virus-specific DNA fragments using two sets of primer pairs. The first primer pair consisted of a virus-specific primer $5^{\prime}$-IP1 and the abridged anchor primer (AAP) supplied with the $5^{\prime}$ RACE kit. A second nested PCR was performed using the first PCR product as template with virus-specific primer $5^{\prime}$-IP2 and the abridged universal amplification primer (AUAP) supplied with the 5'RACE kit. To eliminate ambiguity in the terminal nucleotide sequence of GLRaV-1, cDNA obtained from dsRNA with primer 5'-OP was dA-tailed, instead of dC-tailing, as described above and used as template in PCR to amplify DNA fragments with virus-specific primer 5'-IP1 and a modified AAP primer containing oligo (dT) sequence (mAAP). A second nested PCR was carried out as described above with 5' -IP2 and AUAP. For determining $3^{\prime}$ end of the virus genome, total RNA was dA-tailed with Yeast Poly(A) polymerase (USB, Cleveland, $\mathrm{OH}$ ) and used as template in RT-PCR with virus specific primer $3^{\prime}$-NTR-F and M111 (an oligo (dT) primer). The PCR amplifications were performed as described above and the amplicons were cloned into pCR2.1-TOPO vector (Thermo Fisher Scientific) and transformed into E. coli as described above. Recombinant DNA isolated from several independent colonies per amplicon were sequenced in both orientations (Retrogen, Inc., San Diego, CA).

Mapping transcriptional start sites of subgenomic RNAs. Total RNA extracted from cambial scrapings of virus-infected grapevines was used as a template to synthesize the first-strand cDNA using gene-specific primers. The dC-tailed cDNA was used in PCR with gene-specific nested primers and adapter primers (AAP and AUAP) supplied with the 5'RACE kit, followed by cloning and sequencing as described above. The sequences were aligned with the genome sequence of GLRaV-1 WA-CH and WA-PN isolates to identify transcriptional start sites (TSS) and determine the size of leader sequence corresponding to individual sgRNAs. When necessary, the dA-tailing method described above was used to resolve ambiguity of the $5^{\prime}$ terminal nucleotide (nt) of sgRNAs.

RT-PCR-based restriction fragment length polymorphism (RFLP) method for molecular typing of GLRaV-1 isolates. The $5^{\prime}$ nontranslated region (NTR) sequences of GLRaV1 isolates obtained in this study were screened in silico for the presence of unique restriction enzyme sites using NEBcutter V2.0 (New England Biolabs, Ipswich, MA). Amplicons of approximately 900 nt length, covering the entire $5^{\prime}$ NTR and 44 nt of the N-terminal portion of the ORF1a, were generated by RT-PCR using total RNA and primers VA-F and 5'-OP and subjected to restriction digestion with XhoI (New England Biolabs), according to the manufacturer's instructions. The digested products were resolved in $1.5 \%$ agarose gels and visualized under UV transilluminator as described above.

Northern blot hybridization. Total RNA from virus-infected grapevines was resolved in formaldehyde denaturing $1.1 \%$ agarose gels in MOPS buffer and transferred onto a nylon membrane using an electrotransfer unit (Hoefer Pharmacia Biotech, San Francisco, CA). Prehybridization and subsequent hybridization using nonradioactive digoxigenin (DIG)-labelled riboprobes were carried out essentially as described in Jarugula et al. (2010). For preparing the riboprobe, sequences specific to the $\mathrm{p} 24$ ORF was amplified from a cDNA clone using the primers p24 probe-R, containing SP6 RNA polymerase promoter sequence, and p24 probe-F. The approximately $630 \mathrm{nt}$ amplicons were gel purified with GeneClean III Kit, according to the manufacturer's instructions (MP Biomedicals). The purified amplicons were used as a template to generate nonradioactive DIG-labeled riboprobes using SP6 RNA polymerase and nucleotides containing DIG-labeled UTP (DIG RNA labeling kit [SP6/T7], Sigma-Aldrich, St. Louis, MO), according to the manufacturer's instructions.

Sequence and secondary structure analysis. Nucleotide sequences were analyzed using Vector NTI Advance version 11 software (Thermo Fisher Scientific). Multiple alignments of nucleotide and amino acid (aa) sequences were made using CLUSTAL W (Thompson et al. 1994) and CLUSTAL Omega (Sievers et al. 2011). The evolutionary distances were estimated using the Jukes-Cantor method (Jukes and Cantor 1969) and the phylogenetic relationships were inferred by employing the neighbor-joining algorithm (Saitou and Nei 1987) with 1,000 bootstrap replications (Felsenstein 1985) using the Molecular Evolutionary Genetic Analysis software version 7 (MEGA 7) (Kumar et al. 2016). Secondary structure analysis of GLRaV-1 sequences was carried out using MFOLD software (Zuker 2003). Repeat sequences in the viral genome were identified using the online tool "tandem repeat finder" at https://tandem.bu.edu/trf/trf. $\mathrm{html}$ (Benson 1999). Conserved domains in GLRaV-1 ORF1a/b were identified using NCBI Conserved Domain search tool (https://www. ncbi.nlm.nih.gov/Structure/cdd/wrpsb.cgi).

\section{RESULTS}

Genome features of two new GLRaV-1 isolates. The genome of WA-CH and WA-PN isolates was amplified into four overlapping cDNA fragments using sequence-specific primers. The derived cDNA clones specific to each fragment were sequenced in both orientations by 'primer walking' using progressive sequencespecific primers. Sequences generated from cDNA clones and 5'and 3 '-terminal sequences were assembled into full-length genome sequence. The genome of GLRaV-1 thus determined was $18,731 \mathrm{nt}$ in length for the WA-CH isolate (KU674796) and 18,946 nt in length for the WA-PN isolate (KU674797). The difference in length between the two isolates was largely due to variation in the size of $5^{\prime}$ and $3^{\prime}$ NTRs and an extra sequence present in the intergenic region (IGR) between ORF1b and p7 in the WA-PN isolate (described below). The genome size of WA-CH and WA-PN isolates was larger than the 18,659 nt reported for the Canadian isolate (NC_016509). However, it should be noted that nucleotide sequence of the Canadian isolate was generated using Illumina sequencing and the $5^{\prime}$ - and $3^{\prime}$-terminal ends were not confirmed.

The genome of GLRaV-1 WA-CH and WA-PN isolates encodes nine predicted ORFs (Fig. 1). The organization of these ORFs was identical in both isolates and similar to the arrangement reported in the partial genome sequences of the Canadian (NC_016509) and Australian (AF195822) isolates. The nucleotide and amino acid sequence identity of individual ORFs encoded by WA-CH and WA-PN isolates were compared among themselves and with corresponding sequences of the Australian and Canadian isolates (Table 1). The WA-CH and WA-PN isolates shared $96.83 \%$ identity at the nucleotide level. Comparisons with the genome of Australian and Canadian isolates were not made due to the lack of complete genome sequence for these two isolates. However, pairwise comparison between ORFs encoded by all four GLRaV-1 isolates showed nucleotide and amino acid sequence identities ranging between 75 and 90\%, except for the CP and CPd1. Only the CP and CPd1 of the Canadian and Australian isolates showed more than $90 \%$ identity at amino acid level with the corresponding ORFs encoded by WA-CH and WA-PN isolates. Overall, ORF-byORF comparisons suggested that the two GLRaV-1 isolates from Washington are more closely related to each other than either of them to the Canadian and Australian isolates. A notable difference in length of the IGR between ORF $1 \mathrm{~b}$ and ORF 2 (p7) was observed among the four isolates, which varied between 754 and $965 \mathrm{nt}$ (WA-CH: $770 \mathrm{nt}$, WAPN: 965 nt, Canada isolate: 754 nt, and Australia isolate: $796 \mathrm{nt}$ ). The large size IGR in WA-PN isolate was due to the presence of a 190-nt-long repeat between nt 9079 and 9434. Interestingly, the WA-PN isolate also differed with other isolates in having a $29 \mathrm{nt}$ repeat in the IGR between $\mathrm{p} 55$ and the $\mathrm{CP}$. 
The ORF1a, potentially encoding a protein with a predicted molecular mass of $\sim 244 \mathrm{kDa}$, contains signature papain-like leader protease (L-Pro), methyl transferase (MET), an Alkylation B (AlkB), and helicase (HEL) domains. The L-Pro domain, mapped putatively between aa 297 and 371 in the $5^{\prime}$-region of ORF1a, has conserved catalytic cysteine $(\mathrm{C})$ and histidine $(\mathrm{H})$ residues, characteristic of papain-like proteases in positive-strand RNA viruses (Gorbalenya et al. 1991; Peng et al. 2001). The MET and HEL domains were putatively mapped, respectively, between aa 444 and 766 and aa 1900 and 2164 in the ORF1a. The MET domain contained six conserved motifs characteristic of the Sindbis-like group of positive-strand RNA viruses and the HEL domain had seven conserved motifs associated with the Superfamily 1 helicase of positive-strand RNA viruses (Gorbalenya and Koonin 1993; Gorbalenya et al. 1990; Koonin et al. 1993; Rozanov et al. 1992). The AlkB domain was putatively mapped to aa $1527-1645$ between MET and HEL domains in the ORF1a. A comparison between the homologs of AlkB, a member of the 2OG-Fe(II) oxygenase superfamily (Aravind and Koonin 2001; van den Born et al. 2008), in ampeloviruses showed the presence of a 'core domain' with signature 'HxD' ( $\mathrm{H}$, Histidine and $\mathrm{D}$, Aspartic acid) motif, a single $\mathrm{H}$ residue, and the $\operatorname{RxxxxR}(\mathrm{R}$, Arginine) motif conserved in GLRaV1, -3 , and -4 and its strains (Fig. 2).

Similar to members of the family Closteroviridae (Dolja et al. 2006), the ORF1b is likely expressed by a +1 ribosomal frameshifting mechanism, yielding a $\sim 300-\mathrm{kDa}$ fusion protein. By comparison with GLRaV-3, a conserved sequence 'GCUUUCGA' was likely the putative site for +1 ribosomal frameshifting (Fazeli and Rezaian 2000). The sequence UUUC, upstream of the stop codon of ORF1a, encodes phenylalanine in both the 0 (UUU) and +1 (UUC) frame and could possibly be the shift site promoting +1 ribosomal frameshifting. ORF1b contained all eight conserved motifs reported in the RdRps of positive-strand RNA viruses (Koonin et al. 1993). The proteins encoded by the downstream ORFs 2 to 9 of GLRaV-1 WA-CH and WA-PN isolates (Fig. 1A) showed characteristics similar to the corresponding proteins described previously (Fazeli and Rezaian 2000; Habili et al. 2007).

GLRaV-1 uniquely possesses CP-like domain in four genes. It has been shown that the $\sim 64-\mathrm{kD}$ a protein, upstream from the $\mathrm{CP}$ gene, encoded by closteroviruses contain C-terminal domain homologous to the CP (Kiss et al. 2013; Napuli et al. 2003). An analysis of the p55-kDa protein, a homolog of the $\sim \mathrm{p} 64-\mathrm{kDa}$ protein, encoded by GLRaV-1 WA-CH and WA-PN isolates revealed the presence of conserved $\mathrm{R}$ and $\mathrm{D}$ residues at position 404 and 441, respectively, in the C-terminal region (Fig. 3), suggesting the presence of $\mathrm{CP}$-homologous domain in the $\mathrm{p} 55-\mathrm{kDa}$ protein. In multiple alignments, the two invariant $\mathrm{R}$ and $\mathrm{D}$ residues were also conserved at near equal distance in $\mathrm{CP}, \mathrm{CPd} 1$ and $\mathrm{CPd} 2$ encoded by the two GLRaV-1 isolates. Based on multiple alignments with p55 orthologs, CPs, and CPm's of other GLRaVs (Fig. 3), and by comparing with available sequences of closterovirus p64 orthologs and CPs and CPm's (data not shown), it can be concluded that CPhomologous domain is uniquely present in four genes (p55, CP, $\mathrm{CPd} 1$, and $\mathrm{CPd} 2$ ) of GLRaV-1 compared with CP-like domain present in three genes (p64 orthologs, CP, and $\mathrm{CPm}$ ) of Closteroviridae members, including other GLRaV species, sequenced so far.
Sequence variation in the $5^{\prime}$ and $3^{\prime}$ NTRs. The 5' NTR of GLRaV-1 WA-CH and WA-PN isolates was 857 and 922 nt in length, respectively. Like other closteroviruses, the $5^{\prime}$ NTR sequences of GLRaV-1 isolates were $\mathrm{A} / \mathrm{U}$ rich $(63 \%)$. The 5' terminal nucleotide was determined as guanine $(\mathrm{G})$, similar to that in Beet yellows virus (BYV), Lettuce infectious yellows virus (LIYV), GLRaV-7, and -4 and its strain -6 (Agranovsky et al. 1994; Ghanem-Sabanadzovic et al. 2012; Jelkmann et al. 2012; Klaassen et al. 1995). A pairwise comparison of 5' NTR sequences revealed the presence of unique signature repeat sequences (Fig. 4A), as was previously reported in GLRaV-3 (Jarugula et al. 2010). A stretch of 65 -nt-long sequence was repeated four times in WA-CH (and in Canadian isolate), whereas the 65 -nt-long sequence was repeated five times in WA-PN isolate. These repeats were positioned between nt 181 and 440 in WA-CH and nt 181 and 494 in WA-PN isolates. A comparison of the 65-nt-long repeats in the two isolates showed sequence identities ranging between 50 and $92 \%$. The extra 65 -nt-long repeat sequence present between nt 441 and 494 in WAPN isolate showed 50 to $78 \%$ sequence identity with the other four sequence repeats.

To verify that the observed 65-nt-long repeats in the $5^{\prime}$ NTR are not due to errors during RT-PCR, cloning or sequencing, petiole extracts from GLRaV-1-infected grapevines (Chardonnay, Pinot noir, Cabernet Sauvignon, and Sauvignon Blanc) were subjected to RT-PCR using primers VA-F and 5'OP. Sequence analysis of cloned amplicons ( $~ 900 \mathrm{nt})$ confirmed the presence of four 65 -ntlong repeats in the 5' NTR of virus isolates from Chardonnay, Cabernet Sauvignon, Pinot noir, and Sauvignon Blanc and five 65-nt-long repeats in some isolates only from Pinot noir. A comparison of the secondary structures predicted by the MFOLD program showed that the $5^{\prime}$ NTRs of both isolates could be folded into a complex secondary structure consisting of a long stem-loop (SL) structure with several sub-structural hairpin loops of variable lengths (data not shown). The length of $3^{\prime}$ NTR of GLRaV-1 WA$\mathrm{CH}$ and WA-PN isolates was 456 and $410 \mathrm{nt}$, respectively. The difference in length was due to the presence of an extra $44 \mathrm{nt}$ sequence between nt 18,548 and 18,591 in the WA-CH isolate (Fig. 4B). The 3' NTR of GLRaV-1 isolates from Canada (NC_016509) and Australia (AF195822) was reported to be 468 and $360 \mathrm{nt}$, respectively. A 23-nt sequence reported at the $3^{\prime}$ terminus of the Canadian isolate between 18,637 and 18,659 nt was not observed in the $3^{\prime}$ termini of WA-CH and WA-PN isolates. An attempt to amplify the $3^{\prime}$ terminal sequence of WA-CH or WAPN isolates from infected grapevine samples using the primer 3' NTR-F and the primer complementary to nt 18,637 to 18,659 in the Canadian isolate failed to yield the expected amplicons (data not shown). Conversely, the primers 3' NTR-F and VD-R successfully amplified the expected $3^{\prime}$ NTR sequence from cultivars Chardonnay, Cabernet Sauvignon, Pinot noir, and Sauvignon Blanc infected with WA-CH or WA-PN isolates. This anomaly suggests that the $3^{\prime}$ terminal $23 \mathrm{nt}$ sequence reported in the Canadian isolate may be an artifact and do not constitute an integral part of the $3^{\prime}$-terminus of GLRaV-1. The 3' NTR of the Australian isolate is shorter in length compared to the $3^{\prime}$ NTR sequence in WA-CH and WA-PN isolates. The difference could be due to mispriming of oligo (dt) primer, resulting in shorter $3^{\prime}$ NTR in the Australian isolate. Similar to the $5^{\prime}$ NTR, the predicted secondary

TABLE 1. Percent nucleotide and amino acid (in parenthesis) sequence identities between nontranslated regions and protein-coding genes of Grapevine leafrollassociated virus 1 isolates from the United States (Washington State), Australia, and Canada ${ }^{\mathrm{a}}$

\begin{tabular}{|c|c|c|c|c|c|c|c|c|c|c|c|c|}
\hline & $5^{\prime}$ NTR & ORF 1a & ORF $1 b$ & p7 & HSP70h & p55 & $\mathrm{CP}$ & CPd1 & $\mathrm{CPd} 2$ & p21 & p24 & $3^{\prime}$ NTR \\
\hline WA-CH $\times$ WA-PN & 93.7 & $97.02(97.19)$ & 98.3 (98.86) & 97.22 (94.92) & 97.92 (98.34) & 96.55 (95.23) & $97.32(98.14)$ & 97.67 (98.4) & 95.99 (94.09) & $97.72(98.41)$ & 96.84 (95.24) & 93.92 \\
\hline WA-CH & $87.84 *$ & $94.48(9$ & 96.01( & $83.33(88$. & $.95)$ & $81.78(8$ & $58(9$ & 84.83 & 78.61( & 79.3 (79.89) & $81.2(8$ & $71.55^{*}$ \\
\hline WA-CH $\times$ AUS & - & $79.23 *(91.71) *$ & $82.13(90.89)$ & 91.67 (89.83) & 90.99 (93.37) & 88.61 (88.38) & $91.23(92.86)$ & 90.62 (91.8) & $86.24(84.09)$ & 88.95 (86.77) & $88.78(86.67)$ & $74.72 *$ \\
\hline WA-PN $\times$ CAN & $86.43 *$ & 94.68 (95.09) & $96.2(97.49)$ & $83.89(89.83)$ & $83.7(88.21)$ & 82.19 (82.99) & 86.58 (95.03) & $84.63(88.2)$ & $78.84(74.32)$ & $79.12(80.42)$ & 80.73 (81.9) & $79.32 *$ \\
\hline WA-PN $\times$ AUS & - & $78.90 *(91.96) *$ & 82.01 (91.27) & 91.11 (88.14) & 90.44 (92.63) & $87.92(87.34)$ & 91.23 (93.17) & 90.55 (91.8) & $86.17(84.09)$ & $89.3(88.36)$ & $88.31(86.19)$ & $73.33 *$ \\
\hline CAN $\times$ AUS & - & $79.23 *(91.46) *$ & $81.15(90.33)$ & 83.89 (86.44) & $84.13(89.01)$ & 82.04 (81.44) & 85.35 (92.86) & $83.83(86.98)$ & $78.76(74.05)$ & $78.60(73.95)$ & $78.52(80.48)$ & 68.00 \\
\hline
\end{tabular}

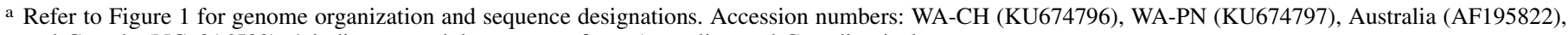
and Canada (NC_016509). * indicates partial sequences from Australian and Canadian isolates. 
structure of $3^{\prime}$ NTRs of WA-CH and WA-PN isolates showed complex structures consisting of several SL structures (data not shown).

A comparison of the size of $5^{\prime}$ and $3^{\prime}$ NTRs of GLRaV-1 WA-CH and WA-PN isolates with the size of corresponding sequences in other members of the family Closteroviridae is presented in Table 2. The data showed that GLRaV-1 has the second largest 5' NTR varying in size between 857 and 922 nt, after the recently reported GLRaV-13 that had 1,100-nt-long 5' NTR. GLRaV-3 ranked third in having a 5' NTR varying in size between 672 and 802 $\mathrm{nt}$, followed by Blackberry vein banding associated virus (BVBaV) with a 781-nt-long 5' NTR. GLRaV-1 WA-CH and WA-PN isolates also differed from other closteroviruses in having a long $3^{\prime}$ NTR consisting of 456 and $410 \mathrm{nt}$, respectively. Outside the genus Ampelovirus, a 692 and 584-nt-long 5' NTR was reported in RNA 2 of LIYV and Tomato chlorosis virus, respectively, and a 511- and 465-nt-long 5' and 3' NTR, respectively, in RNA 2 of Bean yellow disorder virus.

LChV-2
GLRaV-Car
GLRaV-Pr
GLRaV-5
GLRaV-9
GLRaV-4
GLRaV-6
GLRaV-13
GLRaV-3
GLRaV-1_Canada
GLRaV-1_WACH
GLRaV-1_WAPN

LChV-2
GLRaV-Car
GLRaV-Pr
GLRaV-5
GLRaV-9
GLRaV-4
GLRaV-6
GLRaV-13
GLRaV-3
GLRaV-1_Canada
GLRaV-1_WACH
GLRaV-1_WAPN
GL

$\mathrm{LChV}-2$

GLRaV-Car

GLRaV-Pr

GLRaV-5

GLRaV-9

GLRaV-4

GLRaV-6

GLRaV-13

GLRaV-3

GLRaV-1_Canada

GLRaV-1 WACH

GLRaV-1_WAPN
PNLDLNRETSLRLRGRDAWFESRSGDAYGHDKVSYVVLPWARELDRLVDCFGD----ENT ---DLPLVSGDVMRNRSAWFYSRGGESYSYTGGSHRSRGWLDILDAYISACGLEPELFDH ---PLPLLRGDSMNNREAWFYSRGGEGYSYTGYSHRSRGWLSILDRFVSATGLRSSMFDH ---SLPLVNGDRLNGREAWFYSRNGDSYSYVGGSHESRGWLNILNRFVASTGLNPSMFNH ---SLSLVNGDRLNGREAWFYSRNGDSYSYVGGSHESRGWPNILNRFVAATGLNPAMFNH ---PLPLIGGDRLNGREAWFYSRKGDGYSYVGGSHVSRGWLNILNRYISNTGLNPNLFDH ---PLPLIGGDRLNGREAWFCSRNGDPYSYVGGSHNSRGWPNVLNRYIVNTGLNPAT FNH CLPRPNFNETDRVRGREIVLYTREQEVYTYGPISHTGQSWFEGLDEILRKTEG-DLSYNQ TRESNAFTEVDNLRGRSAVFFSRLGEGYTYNGGSHVSSGWPRVLEDILTAIRY-PSVEDH RRLVSSDIFVDKLRGRDVAFYSKYSRRYVYNGGSHASQGWNRALDELREELRL-DESYDH RRLVCSDIFVDRLRGREVAFFSRCSRRYVYNGGSHASQGWNRALDELREELRL-DESYDH RRIVCSDIFVDKLRGREVAFFSKCSRGYVYNGGSHASQGWNRALDELREELRI-DESYDH

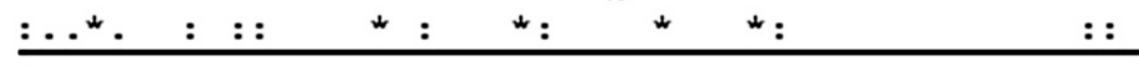

ALVQRYTLGGYVSWFADDEPCYSHDDSIVTINFNGQAVFSIQSGNIYRSF--SLLDRSVL CIIQKYQPDSGLNFHRDDEPVYPRMNPVIRIHASGTGVFSVCCNEGSGQL--DMTDPCYF CLIQRYNRGAGI P FHRDNEPVYPIGNPIIT IHLSGEGMFSIRCGTGCGEL--IMTRPCWF CLVQRYRAGAGI PYHRDNE PVYPRNNPILT IHVSGEGMFSVRCINSSGEI--MLREPCWF CLVQRYRAGAGI PYHRDNE PVYPRNNPIITIHVSGEGMFSVRCINSSGEI--MLREPCWF CLIQKYECGAGI PYFRDNE PVYPRNNPIIT IHVSGEGMFS IRCNNGSGGV--LLRPPSWF CLIQRYVAGAGI PYHRDNEAVYPRNNPIITIHVSGEGMESIRCYDGSGRI--PMREPCWF CLVQRYPEGTMI PLHSDNEACYEPDHRVLTVNLTGRALFSVRCNVGGGSA--TLGNDEWF CLVQRYRMGGGVPFHADDEECYPSDNPIITVNLVGRANFSIRCRRGGRVMVINVASGDYF CLIQRYRRGATIGFHADDERCYTSGVSVVTVNLNGQARFRVRSNRTGEIVEHLIGDGDVF CLIQRYRRGATIGFHADDERCYTSGVSVVTVNLNGQARFRVRSNRTGEVVEHLLGDGDVF CLIQRYRRGATIGEHADDERCYT PGVSVVTVNLNGQARFRVRSNRTGEVVEHILGDGDVF

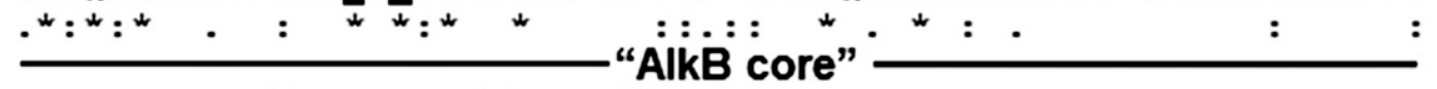

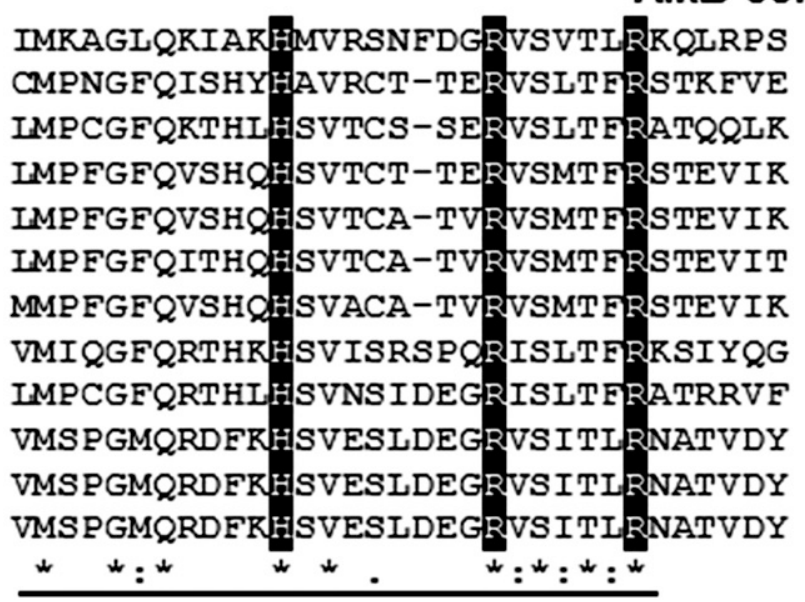
(aa. 0900-1046) (aa. 1606-1752) (aa. 1612-1758) (aa. 1673-1819) (aa. 1363-1509) (aa. 1663-1809) (aa. 1660-1806) (aa. 1494-1642) (aa. 1546-1697) (aa. 1500-1651) (aa. 1500-1651) (aa. 1500-1651)

Fig. 2. Amino acid sequence alignment showing the AlkB domain among grapevine-infecting ampeloviruses. The core of the AlkB domain is marked with a solid line below the alignment based on van den Born et al. (2008). The putative AlkB region corresponding to amino acid residues in the ORF1a/b are shown at the end of each virus sequence. The conserved residues in two motifs (H-X-D- $\mathrm{X}_{\mathrm{n}}-\mathrm{H}$ and $\mathrm{R}-\mathrm{X}_{5}-\mathrm{R}$ ) of the AlkB (Aravind and Koonin 2001; van den Born et al. 2008) are shown with a dark shade. Below the multiple sequence, identical residues are shown with an asterisk $(*)$ and residues with strong and weak similarity are shown with a colon (:) and dot (.). Accession numbers of viral sequences used in the analysis include Grapevine leafroll-associated virus 1 (GLRaV-1) isolates WA-CH (KU674796), WA-PN (KU674797) and Canada (NC_016509), GLRaV-3 (GU983863), GLRaV-4 (FJ467503), GLRaV-5 (JX559640), GLRaV-6 (NC_016417), GLRaV-9 (AY297819), GLRaV-Pr (NC_011702), GLRaV-Car (FJ907331). Sequence in the AlkB domain from Little cherry virus 2 (LChV-2; AF531505) was used for comparison. 
RT-PCR-RFLP assay to distinguish molecular variants of GLRaV-1. The 5' NTR sequences of WA-CH and WA-PN isolates were used to identify the presence of molecular variants of $\mathrm{GLRaV}-1$ in vineyards. Amplicons generated with primers VA-F and 5'-OP from virus-infected vines (cultivars Chardonnay, Pinot noir, Cabernet Sauvignon, and Sauvignon Blanc) were cloned and their sequence determined. A phylogenetic analysis using the neighborjoining algorithm showed segregation of these sequences into three distinct clades (Fig. 5A), with the majority of virus sequences obtained from all four cultivars clustering into group-I and a few virus sequences from Chardonnay and Pinot noir vines forming group-II and group-III. Multiple sequence alignment showed 93\% identity between $5^{\prime}$ NTR sequences of isolates in group-I and -II, whereas $5^{\prime}$ NTR sequences of isolates in group-III showed $82 \%$ identity with corresponding sequences in group-I and -II.

Following an in silico analysis of the $5^{\prime}$ NTR sequences, XhoI restriction enzyme was found to be a reliable marker for developing a RT-PCR-RFLP assay to discriminate GLRaV-1 isolates in vineyards. The $\sim 900$ base pair (bp) DNA fragments amplified in RT-PCR using primers VA-F and 5'-OP were digested individually with $X h o I$ and resolved by agarose gel electrophoresis. The results showed unique restriction patterns distinguishing isolates corresponding to the three groups (Fig. 5B). The 59 NTR sequences in group-II gave two DNA bands of $\sim 650$ and $200 \mathrm{bp}$ in size due to the presence of a single XhoI site and those in group-III gave three bands of $\sim 550,250$, and $130 \mathrm{bp}$ in size due to the presence of two XhoI sites. Conversely, the $5^{\prime}$ NTR sequences of isolates from group-I gave a single uncut band of $860 \mathrm{bp}$ in size due to the absence of $X h o$ I site. These results indicated that phylogenetic segregation of $5^{\prime}$ NTR sequences into three groups is in congruence with RFLP analysis (Fig. 5) and the RT-PCR-RFLP can be used for discrimination of molecular variants of the virus in vineyards.

Expression of $3^{\prime}$-coterminal sgRNAs and identification of transcription start sites. By analogy with other closteroviruses (Dolja et al. 2006), ORFs downstream of the RGB would be expected to express via 3 '-coterminal sgRNAs (Fig. 1C). Fazeli and Rezaian (2000) observed three sgRNAs, when dsRNA isolated from
GLRaV-1-infected grapevines was analyzed by Northern blot hybridization using riboprobes specific to the $3^{\prime}$-end of the virus genome. These sgRNAs were putatively assigned to the CP, p21, and p24 ORFs. To extend these studies, total RNA was isolated from cambial scrapings of canes collected from GLRaV-1-infected vines and analyzed by Northern blot hybridization with riboprobes specific to the p24 ORF. As shown in Figure 1C, three sgRNA bands were detected at higher levels and putatively designated as sgRNAs specific to the CP, p21, and p24, respectively. Among them, the sgRNA corresponding to p24 ORF was found at the highest level, followed by CP and p21 sgRNAs, respectively. Two barely visible bands between $\mathrm{CP}$ and $\mathrm{p} 21$ sgRNAs were tentatively identified as sgRNAs corresponding to CPd 1 and $\mathrm{CPd} 2$. The other poorly visible bands above the CP sgRNA band were tentatively designated as sgRNAs corresponding to p55 and HSP70h/p7, and the genomic RNA. Overall, these results support previous observations (Fazeli and Rezaian 2000) that the $3^{\prime}$-coterminal sgRNAs accumulate at variable amounts, suggesting asynchronous expression levels and/or turnover rates of sgRNAs in GLRaV-1-infected grapevine tissues.

Additional experiments were conducted to determine the leader sequence of $\operatorname{sgRNAs}$. The $5^{\prime}$ terminal sequences corresponding to the CP, CPd1, CPd2, p21, and p24 sgRNAs were amplified by the 5'RACE system and aligned with the genome of GLRaV-1 WA-CH and WA-PN isolates. Adenylate was found to be the $5^{\prime}$-terminal nucleotide in CP and p24 sgRNAs, whereas the 5'end of sgRNAs specific to CPd1, CPd2, and p21 started with guanylate, similar to the $5^{\prime}$-end of the viral genomic RNA. Such a variability in the 5' terminal nucleotide of the sgRNAs was also observed with Sweet potato chlorotic stunt virus (SPCSV) (Kreuze et al. 2002) and BYV (Peremyslov and Dolja 2002; Vitushkina et al. 2007). In contrast, all sgRNAs in Citrus tristeza virus (CTV) (Ayllon et al. 2003) and sgRNAs of GLRaV-3 characterized so far (Jarugula et al. 2010) had adenylate at the $5^{\prime}$-end.

The size of $\mathrm{CP}, \mathrm{CPd} 1, \mathrm{CPd} 2, \mathrm{p} 21$, and p24 sgRNAs was determined by mapping the location of the 5-terminal nucleotide (TSS) of each sgRNA in the genome sequence of WA-CH and

\begin{tabular}{|c|c|c|c|c|}
\hline 55_GLRaV-1 & $98-448$ & $(482)$ & REISSVFAGITLQLRQLGNINTV-VWPDVVL--SN---PCLGE & \\
\hline $63^{-}$GLRaV-2 & & (551) & QFNGARAYEAFKIFKNGNVSFK----PISRLNVPREFWYLN & FRHAN \\
\hline $55^{-}$GLRaV-3 & & & VLCRYYSDLTCLARRHYGIRRN-NWKTLSY--VD---GTL & 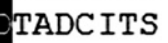 \\
\hline $60^{-}$GLRaV -4 & & & AWCAPLADVAYMLLKDT GGSFA-KWKDMQD--VP---AHM & $Y V$ \\
\hline 61_GLRaV-7 & 487 & & IFCAHRANKAIRINELF-NF"IF & \\
\hline 53_GLRaV-13 & 448 & & LRGTASRAYKLRFENNIKTQ-HSSALAR- & GNF \\
\hline 64 BYV & 463 & 553) & SLSHEAF SIFKRFGVGFE & YRH \\
\hline P_ḠLRaV-1 & & 322) & ARLS SAIAVRLIT & \\
\hline P_GLRaV- & & & & \\
\hline P_GLRaV & & & QYLAYFTPTFITATLNG-KLVM-NEKVMAQHGVPPKFFPY & CVRPTYD \\
\hline P_GLRaV & & & 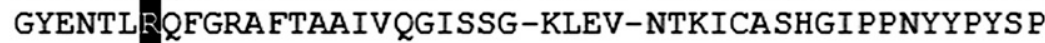 & DAR \\
\hline P_GLRaV & & & MRAKSQEIDKLLIT-MGYVE & AVPLYKK \\
\hline :P_GLRaV & & & FSPSIISASSVG-KIKE & ILRPSY \\
\hline P_BYV & 163 & (204) & CFCRT FQKDYI SFAKEYRGRLP-PIARANRHGLPAEDHY & ISTSTE \\
\hline P'̄1_GLRaV-1 & 407 & $(500)$ & YMRWFSTTTISLIKSG-VVVP-NYHVMARHGVTSQFIP & KCILLPS \\
\hline :Pd2_GLRaV-1 & 429 & $(440)$ & RYMRWWSTATIQLIKLG-IVKP-NPIVAARRGLTNNNLW & IILLDAR \\
\hline Pm_GLRaV-2 & 184 & (223) & FCCACEDLYLTVAPMMSERFK--TKAIGMKGLPVGKE I & ELSGTSK \\
\hline Pm_GLRá & & & IFTHTTITLL & FALLDNR \\
\hline Pm_GLRaV-7 & & & KCGVTIGFEYL & FLDPKEI \\
\hline Pm_GLRaV-13 & & & KYMRWWSATTI SLVKTG-VIKP-NYATQ & VVALDSR \\
\hline BYV & & & TFCAT FEDAYIVIARSL PKLFL- -NRT IG & PTATS \\
\hline
\end{tabular}

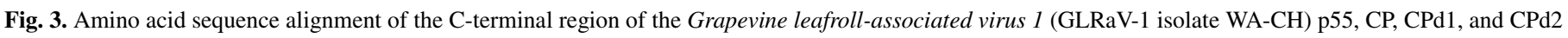

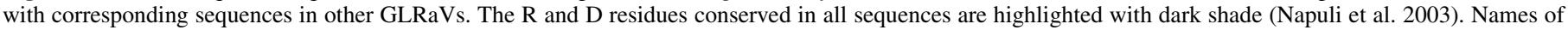

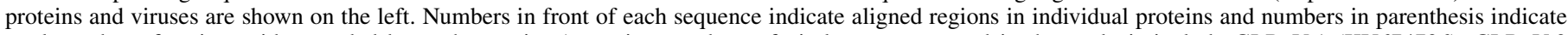

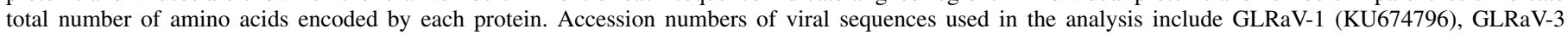

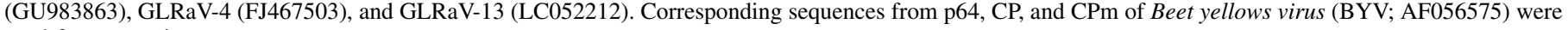
used for comparison. 
WA-PN isolates. The results showed differences in the size of $\mathrm{CP}$, CPd1, CPd2, p21, and p24 sgRNAs (Table 3) due to variation in the length of IGRs and 3' NTRs in WA-CH and WA-PN isolates. However, the size of leader sequence, determined based on the number of nucleotides between TSS and the putative start codon of each ORF, for CPd1, CPd2, p21, and p24 sgRNAs was found to be similar in both WA-CH and WA-PN isolates, except for the CP. A single nucleotide difference in the leader sequence of CP sgRNA

A WACH GTATTGTCCTAGTAGGTATCGAACCAGACAATTCCAATCCTACCATTGCTTTCCATTOCAGATCTGAAATCCACACTTCTTCTCTTCTCTCTGCTTCCGA WAPN GTATTGTCCTAGTAGGTATCGAACCAGACAATCCCAATCCTACCATTGCTTTCCATTOCAGAACTGAAATCCACACTTCTTCTCTTCTCTCTGCTTCCGA Canada --------GTAGGTATCGAACCAGACAATCCCAATCCTACCATTGCTTTCCATTTCAGATCTGAAATCCACACTTCTTCTCTTCTCTCCGCTTCCGA

WACH GCATTCTTCCTCACTTTCCTGTTCAGACACGGCGTGCTGTATAACGGTTCGTTTGTCTTTTCTCGTCTCTCACTTTCTTATTCCTTTTTCTTTCGAGTGC WAPN GCATTCTTTCTCACTTTCCTGTTCAGACACGGCGTGCTGTATAACGGTTCGTTTGTCTTTTCTCGTCTCTCACTTTCTTATTCCTTTTTCTCTCGAGTGC Canada GCATTCTTACTC------10

WACH TAATACCACTCCCTTCTCACCACCCTCTTACATCTGCCTTTTCGTTTCCTTTCTTTCAGGGACGAAGCACATACTTCATCTCTTTATTCTTCTACTTCTT WAPN TAATACCACTCCCTTCTCACCACTCTCTTACATCTCCCTTTTCGTTTCCTTTCTTTCAGGGACGAAGCACACACTTCATCTCTCTACTCTCTTACTTCT Canada TAAAACCACTCCCTTCTCACTACCCTTTTACCTCTCCCTTTTCGTTTCCTTTCTCTCAGGGACGAAGTATATACTTCACCTCTCTACTGTTCTACTTCTT

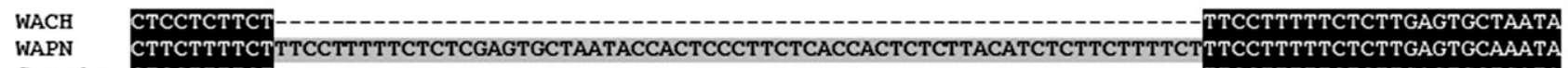
WACH TCACTCCCTTCTTACCACTTTTTCACTTCTCCCTTTTCGTTTCCTTTCACTCAGGGACGAAGCACTAGCTTCTTCTCTTTACTCTTCTACCTCTTCTCCT WAPN TCACTCCCTTCTTACCACTTTTTCATTTCTCCCTTTTCGTTTCCTTTCACTCAGGGACTGAGCACCTGCTTCTTCTCTTTACTTTTCTACCTCTTCTCCT Canada TCACTCTATTCTCACTACTTTTTCACTTCTCCCTTTTTGTTTCCTTTCATTCAGGGACGAAGCACGTACTTCTTCTCTTTACTCTTCTCCCTTTTCTCCT

WACH TTTCTTTCCTTTCTTTTTTATTTTCTATTATATTTTATTTATCCGCCTTCTCTCTTTTCGTACCGATCATTTCCTTTTCTTTTCTTTCTCCTTTTAAATT WAPN TTTCTTTCCTTTCTTTTTCATTTTCTACTTAATTTTATTTATCCGCCTTCTTTCTTTTCGTACCAATCATTTCCTTCTCTTTTCTTTTTCTTTTTAACTT Canada TATCTTTCCTTTCTTTTTTATTTTTTATTTAACTCTATTTATCCGCCTTCTTTCTTTTOGTATCGTTCATTTCCTTCTCTTTTCTTTTTCTTTTTATCGT

WACH TACTTTTTCACCTTCTTTCTTTTTGTATCTATCGTTTCCTTTTCTTTTCTTCATAGTTCGTCACTCATACGTTTTCTCGTTTTCCTCCTTTTCTTAAGTT WAPN TACCTATTCACCCCTTTTCTTTTTGTATCCATCGTTTCCTTTTCTTTTCTTCATAGTTCGTCACTCATACGTTTTCCCGTATTTCTCCTTTTCTTAATAT Canada TACTTTTTCGCCTTCTTTCTTATTGTATCCATCGTTTCCTTTTCTTTTCTCCTTAGTTCGTCACTCTAACGTTTTCCCGAACCACTCCATTTCTTTTCAT

WACH TTCCTTTCATTTCGCGTGCTTCACTTTATAGTATCCCTCCTCTTTTACCGTCTAGGTTTTACCTTTTCCTTTTCCTCTTTAGCATTTTGTTGTTTCGGTT WAPN TTCCTTTTATTTCGCGTGTTTCACTTTATAGTATCCCTCCTCTTTTACTGTCTAGGTTTTATCTTTTCCTTTTTTCTTTTAGCATTTTGCTGTTTCGGTT Canada TTCCTTTCATTTCGCGTGCTTCACTTTATTGTTTCCCCTTTCTTTTACTGTCTAGGTTCTAATTTTTCCTTTTCCTCCTTAGTATTTTGCAGTATCGGTT

WACH TCATTTTTTACATATTTTTCCGTCTTGCGTTTCCTTTTATCTTCGTTTTTCTTGTTTTTGTCGGTCCCTTTTGTTCTCTTTTCTTTTCTCTATTTTTCCT WAPN TCGGTTTTTACGTATTTTTTCGTCTAGCGTTTCCTTTTATCTTCGTTTTTCTTGTCTTTGTCGGTCCCTTTTGTTCTTTTTTCTTTTTGCTATTTTTCCT Canada TCATTTCTAACTTTTTTATTCGTCTTGTACTTCCTTTTATCTTCGCTTTTCTCGTTTTTGTCGTTCCCCATTGTTCTCTTTTCTTATTTTTATATTTCCT

WACH TTCTTCTCGCTTATTTAAAATCATG

WAPN TTCTCCTAGCTTATTTAAAATCATG

Canada TTCTTCTCGTTTATTTAAAATCATG

B

WACH

WAPN

Canada

Australia

WACH

WAPN

Canada

Australia

WACH

WAPN

Canada

Australia

WACH

WAPN

Canada

Australia

WACH

WAPN

Canada

Australia

WACH

WAPN

Canada

Australia

AATAAAGAATTA-ATGAA--AAGTATGTCCGTATCGAGGCTATGAATCAATATCGATGTCCGTCTGT GAAGAGTCAGATGTGATTCGTTTTCGTATCTTCACCAATGAGCAAGAAGAGGTGAATTGGTTGGTATCATTTCCATGATCCAACATCGATGTCCGTCAGT AAACAATCGCTATCGAGTTTTCTACTCATCGTTTCT AGAGAAGAA-AAGAAATAAGTATATCGGTGCCGAGGCTAAGAATCGACATCGATGCOCGTCTGT

GCGAGACATTTATTTTGTT--TTCATGTCTTGAGATTGAGAACAGTAAAACGAAAATGCGATCGTGGCATACTCATCATCATAGAAAAGCGAATTACGCA GCGAGACATTTATTTTGTT--TTCATGTCTTGAGACTGAGAACAGTGAAACGAAAATGCGATCGTGGCATACTCATCATCATAGAAAAAGGTATTACGCA GCGAGACATTTATATTGACAATTGGCGTTCAGAGACTAACAACGGTGAAA----AATGCGGTTATGGCACGTTCACCATCACAAAAGGCGCCAATACGCT GCGAGACATTTAATTTATT--TTCACGTCTTGAAATTAGAGACGGTGATATTATAATGCGGTTATGGCATACTTCTCATCACAGAAAACGCCATTACGCG

CTAATAGATGCATATATATTGTGTGCAATCTTATTAATAATGCTATTAATTCTCGCTTTTTATATACTAAAGAAGAGATTCTTAAAATAAAATAAAATAA CTAATAGATGCATATATATTGTGTGCGATCTTATTAATAATGTTGTTAATGCTCGTTTTTTATATACTAAAGAAGAGATTT TTAAAATAAAATAAAATAA TTAATCGACGCGTATATTATGATTATTATTGTTCTAATAATGTTGTTAGTGCTTACTTTTTATTTAATTAAGAAGAGGCGATTAAGTTAAATTAAAATAA CTAATAGACGCATATATATTGTGTGCGATTTTATTAGTGATGTTGCTAATTCTCATTTTTTATATATTAAAGAAGAGAGTTTTAAAATAAAA----CCAA

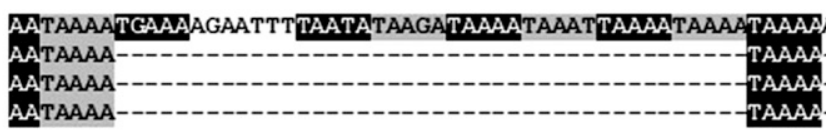

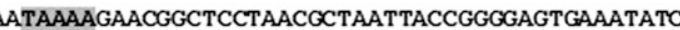
TGAAAAAACGGCTCCCAACGCTAATTACCGGGGAGTGAAATATC -TAAATAAATGGCTCCTAACGCTAATTACCGGGGAGTGAAATATC -TAAAA---TTTCTCGTT-CTTTATATAATGAAGAAGGGGATTTT

GAAATGTTACTTTGTAATAAAATAATCTGAGGGTCTAGGTCCTCAGATTATATAAGTCCTGATAGGGTGAGATATATAAATAAACGGAAACG--------GAGATGTTACTTTGTAATAAAATAATCTGAGGGTCTAGGTTCTCAGATTATATAAGTCCCGTTAGGGTGAGATATATAAAT AAACGGAAACG-------GAAATGTTACTTAGTAATAAGATAATCTGAGGGTCTAGGTTCTCAGATTATATAAGTCCTATTAGGGTGAGATATATAAATAAACGGAAACGCGCGGACA AATATACAACAAATT--

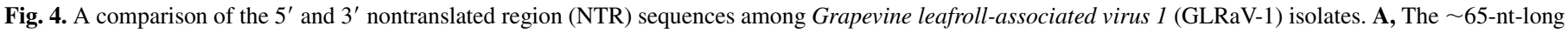

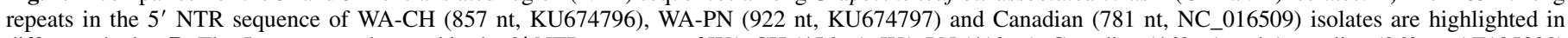

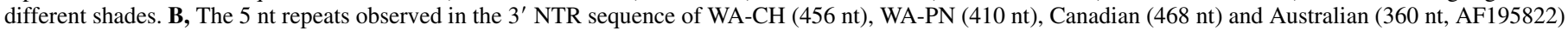

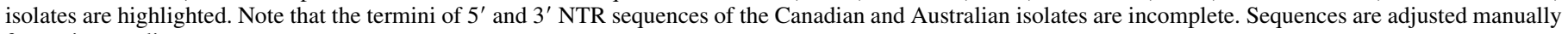
for optimum alignment. 
TABLE 2. Comparison of the size of $5^{\prime}$ and $3^{\prime}$ nontranslated regions (NTR) among viruses in the family Closteroviridae ${ }^{\text {a }}$

\begin{tabular}{|c|c|c|c|c|}
\hline Genus & Virus & $5^{\prime}$ NTR & $3^{\prime} \mathrm{NTR}$ & Accession number \\
\hline \multirow[t]{7}{*}{ Ampelovirus } & GLRaV-1 & $857-922$ & $410-456$ & KU674796, KU674797 \\
\hline & GLRaV-3 & $672-802$ & $259-450$ & $\begin{array}{l}\text { JQ423939, KM058745, GU983863, } \\
\text { JQ796828, JX559645, KJ174518, } \\
\text { GQ352631, GQ352633 }\end{array}$ \\
\hline & GLRaV-4 & $213-218$ & $127-130$ & $\begin{array}{l}\text { KJ810572, NC_016416, NC_011702, } \\
\text { NC_016417 }\end{array}$ \\
\hline & GLRaV-13 & 1,100 & 267 & $\mathrm{LC} 052212$ \\
\hline & PMWaV-1 & 353 & $129-131$ & NC_010178, KJ872494 \\
\hline & PBNSPaV & $301-302$ & $231-247$ & $\begin{array}{l}\text { KC590347, KC590345, КC590344, } \\
\text { KJ792852, NC_009992 }\end{array}$ \\
\hline & $\mathrm{BVBaV}$ & 781 & 335 & NC_022072 \\
\hline \multirow[t]{5}{*}{ Closterovirus } & GLRaV-2 & $105-106$ & $206-215$ & NC_007448, KF220376 \\
\hline & BYV & 107 & $166-182$ & AF056575, NC_001598, AF190581 \\
\hline & CTV & $106-109$ & $267-362$ & GQ454870, EU857538 \\
\hline & CYLV & 324 & 227 & NC_013007 \\
\hline & $\mathrm{SCFaV}$ & 227 & 215 & NC_008366 \\
\hline \multirow[t]{10}{*}{ Crinivirus } & LIYV (RNA 1) & 97 & 218 & NC_003617 \\
\hline & LIYV (RNA 2) & 692 & 191 & NC_003618 \\
\hline & BYDV (RNA 1) & 83 & 249 & NC_010560 \\
\hline & BYDV (RNA 2) & 511 & 465 & NC_010561 \\
\hline & LCV (RNA 1) & 72 & 226 & NC_012909 \\
\hline & LCV (RNA 2) & 268 & 98 & NC_012910 \\
\hline & ToCV (RNA 1) & 93 & 225 & NC_013258 \\
\hline & ToCV (RNA 2) & 584 & 179 & NC_013259 \\
\hline & SPaV (RNA 1) & 264 & 197 & NC_005895 \\
\hline & SPaV (RNA 2) & 240 & 186 & NC_005896 \\
\hline \multirow[t]{3}{*}{ Velarivirus } & GLRaV-7 & 47 & 192 & NC_016436 \\
\hline & LChV-1 & 76 & 207 & NC_001836 \\
\hline & CoV-1 & 67 & 269 & HM588723 \\
\hline
\end{tabular}

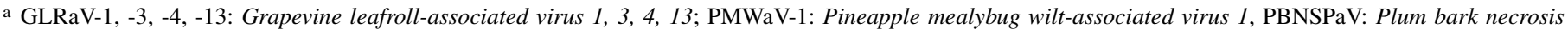
stem pitting-associated virus; BVBaV: Blackberry vein banding associated virus; GLRaV-2: Grapevine leafroll-associated virus 2; BYV: Beet yellows virus; CTV: Citrus tristeza virus; CYLV: Carrot yellow leaf virus; SCFaV: Strawberry chlorotic fleck-associated virus; LIYV: Lettuce infectious yellows virus; BYDV: Bean yellow disorder virus; LCV: Lettuce chlorosis virus; ToCV: Tomato chlorosis virus; SPaV: Strawberry pallidosis-associated virus; GLRaV-7: Grapevine leafroll-associated virus 7; LCV-1: Little cherry virus 1; CoV: Cordyline virus 1.
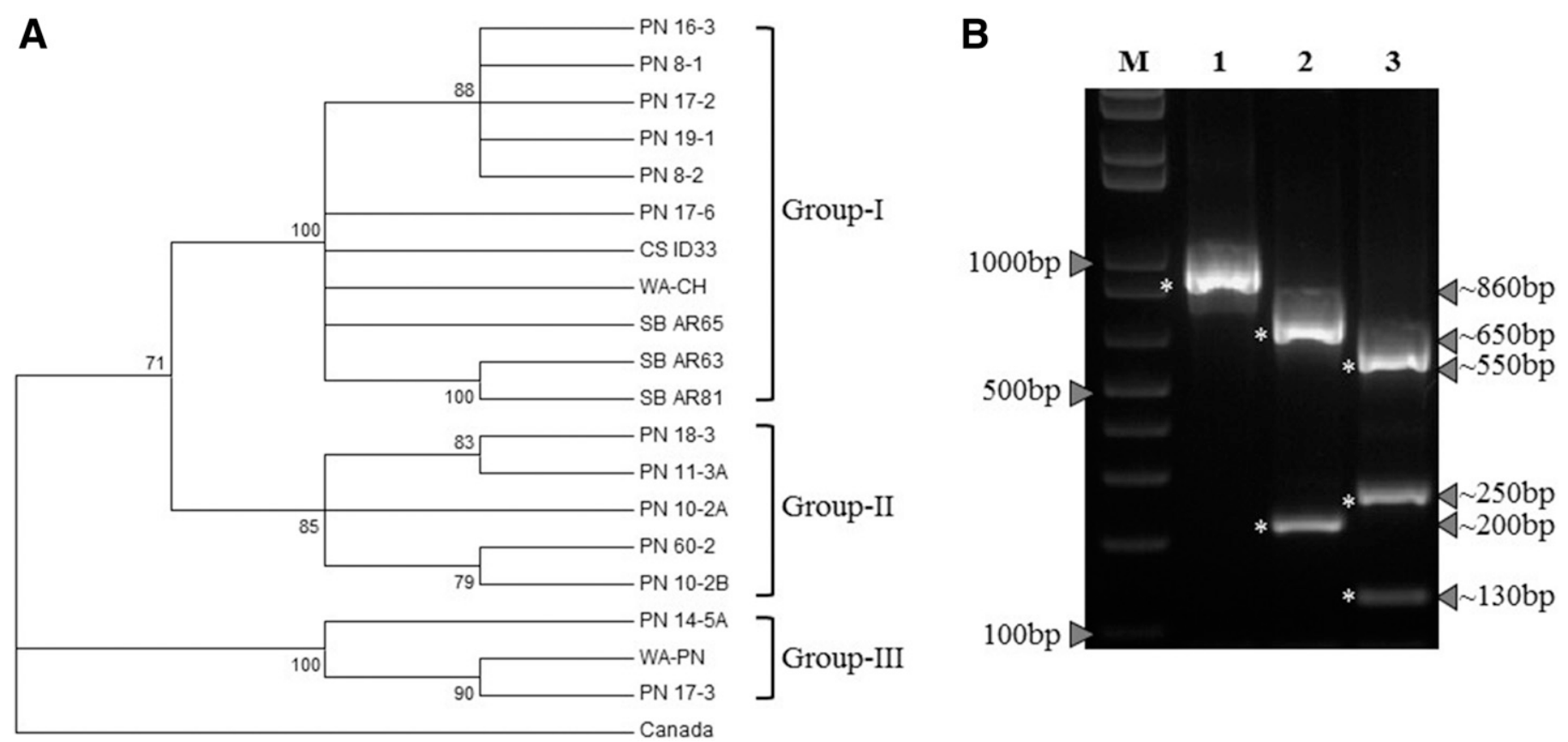

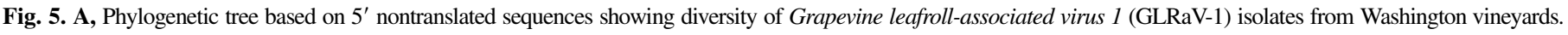

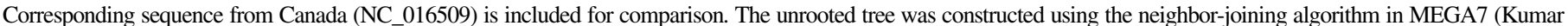

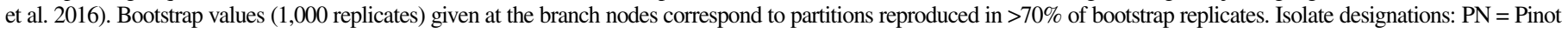

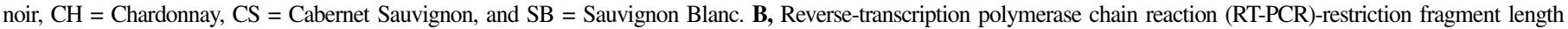

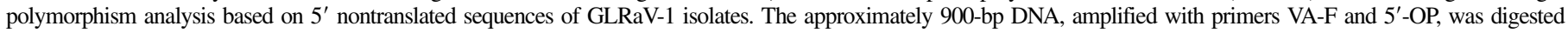

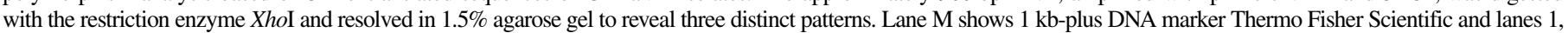

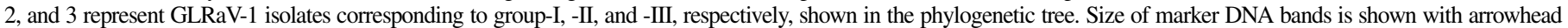
to the left and the estimated size of products of restriction digestion (marked with an asterisk) is indicated by arrowhead to the right. 
between the two isolates was due to an extra nucleotide present in the IGR between p55 and CP in WA-PN (96 nt) compared with the IGR in WA-CH (95 nt). The leader sequence of the CP sgRNA was located entirely within the 95-nt-long IGR between p55 and CP, whereas the leader sequence corresponding to p21 and p24 sgRNAs was located, respectively, within the 79-nt-long IGR between CPd2 and p21 and 43-nt-long IGR between p21 and p24. In contrast, the 26-nt-long leader sequence of CPd1 encompass 4 nt C-terminus of the $\mathrm{CP}$ and 22-nt-long IGR between $\mathrm{CP}$ and $\mathrm{CPd} 1$, and the 15-ntlong leader sequence of CPd 2 encompass $12 \mathrm{nt}$ C-terminus of CPd1 and 3-nt-long IGR between $\mathrm{CPd} 1$ and $\mathrm{CPd} 2$. No conserved sequence motifs were found in the AU-rich leader sequences of these sgRNAs. The exact nucleotide position of the $5^{\prime}$-end of $\mathrm{p} 7$, HSP70h, and p55 sgRNAs were not determined, despite several attempts. This could be, in part, due to low abundance of these sgRNAs (Fig. 1C) in virus-infected grapevine samples used in this study.

\section{DISCUSSION}

In this study, the complete genome sequence of two new GLRaV1 isolates was determined. The sequence data indicated that GLRaV-1 has the second largest genome among monopartite members of the family Closteroviridae, after CTV that has $\sim 19.3 \mathrm{~kb}$ genome (Karasev et al. 1995). Relative to the genome size of 18.5 to $18.7 \mathrm{~kb}$ in GLRaV-3 isolates (Maree et al. 2013) and $18.6 \mathrm{~kb}$ in BVBaV (Thekke-Veetil et al. 2013), the 18.7 to $18.9 \mathrm{~kb}$ size of GLRaV-1 makes it by far the largest genome among members of the genus Ampelovirus. It is interesting to note that viruses with unusually large genome size have been documented only in perennial crops, although the significance of this observation needs further research. Nevertheless, the complete genome sequence of GLRaV-1 WA-CH and WA-PN isolates, together with the complete genome sequences available for other GLRaVs, should provide opportunities for elucidating the molecular biology of grapevine-infecting viruses in the family Closteroviridae.

The overall genome organization of GLRaV-1 WA-CH and WAPN isolates with hallmark gene array consisting of nine ORFs corresponds to that of GLRaV-1 sequences reported from Australia and Canada (Fig. 1). In analogy with their homologs in other members of the family Closteroviridae (Agranovsky et al. 1995; Alzhanova et al. 2001, 2007; Lu et al. 2004; Peremyslov et al. 2004; Reed et al. 2003; Satyanarayana et al. 2000, 2004; Tian et al. 1999), many of the proteins encoded by GLRaV-1 are likely to be multifunctional involved in various aspects of the virus life cycle, including virion assembly, cell-to-cell and systemic movement and suppressors of RNA silencing. Although the occurrence of a diverged duplicate of the $\mathrm{CP}$, designated as $\mathrm{CPm}$, is a common feature with many closteroviruses, the presence of two divergent copies of the CP, CPd1, and CPd2, only in the genome of GLRaV-1 is an exclusive feature of the virus in the family Closteroviridae. GLRaV-1 also provides a unique example of a RNA virus having CP-homologous domain in four genes (p55, CP, CPd1, and CPd2), making the virus an evolutionary novelty among closteroviruses sequenced so far. Although these unique features of GLRaV-1 are likely due to tandem gene duplications or series of events occurred during the evolution and diversification of closteroviruses (Dolja et al. 2006; Simon-Loriere and Holmes 2013), what beneficial functions these gene duplications and multiple homologs of the $\mathrm{CP}$ could confer on the virus life cycle remains to be elucidated. In analogy with BYV (Peremyslov et al. 2004) and CTV (Satyanarayana et al. 2004), GLRaV1 is expected to have a bipolar architecture with virions composed of CP, $\mathrm{CPd} 1 / \mathrm{CPd} 2$, p55, and HSP70h, and the two invariant $\mathrm{R}$ and D residues playing a critical role in the assembly function of $\mathrm{CP}$, as reported earlier with several filamentous viruses (Dolja et al. 1991; Napuli et al. 2003). However, it remains to be studied whether one or both of CPd1 and $\mathrm{CPd} 2$ are integral components of GLRaV-1 virions.

It is noteworthy that WA-CH and WA-PN isolates have a highly variable sequence in the $5^{\prime}$ and $3^{\prime}$ NTRs, whereas coding regions are highly conserved. The most striking feature of GLRaV-1 is the large size 5' NTR, varying between 857 and 922 nt, compared with other members in the family Closteroviridae (Table 2). Besides, the NTRs have tandem repeat sequences, with $\sim 65$-nt-long repeats in the $5^{\prime}$ NTRs and short sequences of $\sim 5 \mathrm{nt}$ repeats in the $3^{\prime}$ NTRs (Fig. 4). Outside the family Closteroviridae, the wheat-infecting Triticum mosaic virus (TriMV) in the family Potyviridae was reported to have a 739-nt-long 5' NTR (Tatineni et al. 2009). Long 5' NTRs between 650 and 1,300 nt in size have been reported in animal/ human-infecting viruses in the family Picornaviridae (Belsham and Sonenberg 1996; Jackson and Kaminski 1995). A unique direct repeat sequence of 32 and $76 \mathrm{nt}$ was reported, respectively, in the $3^{\prime}$ NTR of PVY-N (Robaglia et al. 1989) and an isolate of Pepper mottle virus (Warren and Murphy 2003).

In addition to GLRaV-1, the $\sim 65$-nt-long repeats were reported previously in the 5' NTR of GLRaV-3 (Jarugula et al. 2010). The presence of distinct but similar size repeat sequences only in these two ampeloviruses remains obscure. It would seem likely that these sequence repeats could be playing a regulatory role in virus replication. Preliminary studies with GLRaV-3 have indeed suggested that sequences in the $5^{\prime}$ NTR contains critical element(s) required for virus replication (Jarugula et al. 2012). In the case of CTV, the 5' NTR forms two stable SL structures, despite having high sequence diversity (Lopez et al. 1998) and these structures were shown to be essential for replication and assembly (Gowda et al. 2003). The highly conserved 3' NTR of CTV isolates could be folded into a complex secondary structure composed of 10 SLs and was shown to harbor critical elements for efficient replication of the virus (Satyanarayana et al. 2002). Likewise, the $5^{\prime}$ and $3^{\prime}$ NTRs of GLRaV-1 could be harboring important elements and their functions could be mediated by a combination of linear sequence and secondary structural elements. The availability of infectious clones of GLRaV-1 would help to elucidate the important and diverse roles of repeat sequence elements present in the $5^{\prime}$ and $3^{\prime}$ NTRs in the virus life cycle. Meanwhile, the RFLP analysis of $5^{\prime}$ NTR sequences (Fig. 5B) would offer a practical tool for differentiating GLRaV-1 variants in vineyards without resorting to much elaborate sequence-based identification of virus variants. Together with genetic diversity studies reported earlier (Alabi et al. 2011; Fan et al. 2015; Kominek et al. 2005), knowledge of variability in the $5^{\prime}$ NTR could enhance the power of discriminating

TABLE 3. Characteristics of five subgenomic (sg) RNAs encoded by Grapevine leafroll-associated virus 1 isolates

\begin{tabular}{|c|c|c|c|c|c|c|}
\hline \multirow[b]{2}{*}{ sgRNA } & \multicolumn{3}{|c|}{ WA-CH (KU674796) } & \multicolumn{3}{|c|}{ WA-PN (KU674797) } \\
\hline & TSS position $^{\mathrm{a}}$ & Leader sequence $(\mathrm{nt})^{\mathrm{b}}$ & sgRNA size $(n t)^{c}$ & TSS position ${ }^{a}$ & Leader sequence $(n t)^{b}$ & sgRNA size $(n t)^{c}$ \\
\hline $\mathrm{CP}$ & 13,064 & 67 & 5,668 & 13,324 & 68 & 5,623 \\
\hline CPd1 & 14,096 & 26 & 4,636 & 14,357 & 26 & 4,590 \\
\hline $\mathrm{CPd} 2$ & 15,613 & 15 & 3,119 & 15,874 & 15 & 3,073 \\
\hline p21 & 16,981 & 49 & 1,751 & 17,242 & 49 & 1,705 \\
\hline $\mathrm{p} 24$ & 17,625 & 18 & 1,107 & 17,886 & 18 & 1,061 \\
\hline
\end{tabular}

a Nucleotide number of the transcriptional start site (TSS) in the virus genome sequence.

b Number of nucleotides between TSS and the start codon of the corresponding open reading frame.

c Number of nucleotides between TSS and the $3^{\prime}$ terminal nucleotide in the virus genome. 
GLRaV-1 isolates in epidemiological studies and to infer evolutionary relationships among genetically divergent variants of the virus.

Characterization of the sgRNA profiles by Northern blot hybridization revealed that three of the eight 3 '-coterminal sgRNAs were readily detectable in GLRaV-1-infected grapevines (Fig. 1B). Among the three sgRNAs, the sgRNA specific to the p24 showed higher accumulation followed by the sgRNAs specific to CP and p21, suggesting that genes located nearer to the $3^{\prime}$ end of GLRaV-1 genome are usually expressed at higher levels as reported with BYV and CTV (Hagiwara et al. 1999; Navas-Castillo et al. 1997). In this regard, transcription regulation of GLRaV-1 sgRNAs appears to be similar to these two monopartite closteroviruses than GLRaV-3 (Jarugula et al. 2010). Such asymmetric accumulation of the individual sgRNAs could be due to temporal and quantitative regulation of their expression in virus-infected plants, as reported with other closteroviruses such as CTV (Navas-Castillo et al. 1997), BYV (Hagiwara et al. 1999), LIYV (Yeh et al. 2000), SPCSV (Kreuze et al. 2002), and GLRaV-3 (Jarugula et al. 2010). Further studies are required to examine the expression profile of GLRaV-1 sgRNAs at different phenological stages of infected grapevines to better understand the complex gene expression strategy of the virus.

In summary, the complete genome sequence analysis of two new GLRaV-1 isolates revealed several unique characteristics of the virus relative to other members of the family Closteroviridae. Together with the information generated on the expression of $3^{\prime}$ coterminal sgRNAs, this study provided a foundation for the development of an amenable reverse genetic system to understand virus gene functions and elucidate comparative molecular biology of grapevine-infecting ampeloviruses.

\section{ACKNOWLEDGMENTS}

This research was supported, in part, by the WSU Agricultural Research Center, the Wine Research Advisory Committee, the Washington Wine Commission, the Washington State Grape and Wine Research Program, Northwest Center for Small Fruits Research, and Altria-Chateau Ste. Michelle Wine Estates. We thank S. Gowda for critical review. PPNS Number 0745, Department of Plant Pathology, College of Agricultural, Human, and Natural Resource Sciences Agricultural Research Center Project WNPO 0616, Washington State University, Pullman.

\section{LITERATURE CITED}

Agranovsky, A. A., Lesemann, D. E., Maiss, E., Hull, R., and Atabekov, J. G. 1995. "Rattlesnake" structure of a filamentous plant RNA virus built of two capsid proteins. Proc. Natl. Acad. Sci. USA 92:2470-2473.

Agranovsky, A. A., Koonin, E. V., Boyko, V. P., Maiss, E., Frotschl, R., Lunina, N. A., and Atabekov, J. G. 1994. Beet yellows closterovirus: Complete genome structure and identification of a leader papain-like thiol protease. Virology 198:311-324.

Al Rwahnih, M., Dolja, V. V., Daubert, S., Koonin, E. V., and Rowhani, A. 2012. Genomic and biological analysis of Grapevine leafroll-associated virus 7 reveals a possible new genus within the family Closteroviridae. Virus Res. 163:302-309.

Alabi, O. J., Al Rwahnih, M., Karthikeyan, G., Poojari, S., Fuchs, M. F., Rowhani, A., and Naidu, R. A. 2011. Grapevine leafroll-associated virus 1 occurs as genetically diverse populations. Phytopathology 101:1446-1456.

Alkowni, R., Zhang, Y. P., Rowhani, A., Uyemoto, J. K., and Minafra, A. 2011. Biological, molecular, and serological studies of a novel strain of Grapevine leafroll-associated virus 2. Virus Genes 43:102-110.

Alzhanova, D. V., Napuli, A. J., Creamer, R., and Dolja, V. V. 2001. Cell-tocell movement and assembly of a plant closterovirus: Roles for the capsid proteins and HSP70 homolog. EMBO J. 20:6997-7007.

Alzhanova, D. V., Prokhnevsky, A. I., Peremyslov, V. V., and Dolja, V. V. 2007. Virion tails of Beet yellows virus: coordinated assembly by three structural proteins. Virology 359:220-226.

Aravind, L., and Koonin, E. V. 2001. The DNA-repair protein AlkB, EGL-9, and leprecan define new families of 2-oxoglutarate and iron-dependent dioxygenases. Genome Biol. 2:research0007.1-0007.8.
Ayllon, M. A., Gowda, S., Satyanarayana, T., Karasev, A. V., Adkins, S., Mawassi, M., Guerri, J., Moreno, P., and Dawson, W. O. 2003. Effects of modification of the transcription initiation site context on Citrus tristeza virus subgenomic RNA synthesis. J. Virol. 77:9232-9243.

Belsham, G. J., and Sonenberg, N. 1996. RNA-protein interactions in regulation of picornavirus RNA translation. Microbiol. Rev. 60:499-511.

Benson, G. 1999. Tandem repeats finder: A program to analyze DNA sequences. Nucleic Acids Res. 27:573-580.

Bertazzon, N., Borgo, M., Vanin, S., and Angelini, E. 2010. Genetic variability and pathological properties of Grapevine leafroll-associated virus 2 isolates. Eur. J. Plant Pathol. 127:185-197.

Dolja, V. V., Boyko, V. P., Agranovsky, A. A., and Koonin, E. V. 1991. Phylogeny of capsid proteins of rod-shaped and filamentous RNA plant viruses: Two families with distinct patterns of sequence and probably structure conservation. Virology 184:79-86.

Dolja, V. V., Kreuze, J. F., and Valkonen, J. P. 2006. Comparative and functional genomics of closteroviruses. Virus Res. 117:38-51.

Esteves, F., Santos, M. T., Eiras-Dias, J. E., and Fonseca, F. 2013. Molecular data mining to improve antibody-based detection of Grapevine leafrollassociated virus 1 (GLRaV-1). J. Virol. Methods 194:258-270.

Fan, X. D., Hong, N., Dong, Y. F., Ma, Y. X., Zhang, Z. P., Ren, F., Hu, G. J., Zhou, J., and Wang, G. P. 2015. Genetic diversity and recombination analysis of Grapevine leafroll-associated virus 1 from China. Arch. Virol. 160:1669-1678.

Fazeli, C. F., and Rezaian, M. A. 2000. Nucleotide sequence and organization of ten open reading frames in the genome of Grapevine leafroll-associated virus 1 and identification of three subgenomic RNAs. J. Gen. Virol. 81:605-615.

Felsenstein, J. 1985. Confidence-limits on phylogenies: An approach using the bootstrap. Evolution 39:783-791.

Ghanem-Sabanadzovic, N. A., Sabanadzovic, S., Gugerli, P., and Rowhani, A. 2012. Genome organization, serology and phylogeny of Grapevine leafrollassociated viruses 4 and 6: Taxonomic implications. Virus Res. 163: 120-128.

Gorbalenya, A. E., and Koonin, E. V. 1993. Helicases: Amino acid sequence comparisons and structure-function relationships. Curr. Opin. Struct. Biol. $3: 419-429$.

Gorbalenya, A. E., Koonin, E. V., and Wolf, Y. I. 1990. A new superfamily of putative NTP-binding domains encoded by genomes of small DNA and RNA viruses. FEBS Lett. 262:145-148.

Gorbalenya, A. E., Koonin, E. V., and Lai, M. M. 1991. Putative papain-related thiol proteases of positive-strand RNA viruses. Identification of rubi- and aphthovirus proteases and delineation of a novel conserved domain associated with proteases of rubi-, $\alpha$ - and coronaviruses. FEBS Lett. 288: 201-205.

Gowda, S., Satyanarayana, T., Ayllon, M. A., Moreno, P., Flores, R., and Dawson, W. O. 2003. The conserved structures of the 5 ' nontranslated region of Citrus tristeza virus are involved in replication and virion assembly. Virology 317:50-64.

Habili, N., Komínek, P., and Little, A. 2007. Grapevine leafroll-associated virus 1 as a common grapevine pathogen. Plant Viruses 1:63-68.

Hagiwara, Y., Peremyslov, V. V., and Dolja, V. V. 1999. Regulation of closterovirus gene expression examined by insertion of a self-processing reporter and by northern hybridization. J. Virol. 73:7988-7993.

Ito, T., and Nakaune, R. 2016. Molecular characterization of a novel putative ampelovirus tentatively named grapevine leafroll-associated virus 13 . Arch. Virol. 161:2555-2559.

Jackson, R. J., and Kaminski, A. 1995. Internal initiation of translation in eukaryotes: The picornavirus paradigm and beyond. RNA 1:985-1000.

Jarugula, S., Gowda, S., and Naidu, R. A. 2012. Nucleotide sequence at the beginning of the $5^{\prime}$ nontranslated region is critical for replication of Grapevine leafroll-associated virus 3. Pages 54-56 in: Proceedings of the 17th Congress of ICVG, Davis, CA.

Jarugula, S., Gowda, S., Dawson, W. O., and Naidu, R. A. 2010. 3'-Coterminal subgenomic RNAs and putative cis-acting elements of Grapevine leafrollassociated virus 3 reveals 'unique' features of gene expression strategy in the genus Ampelovirus. Virol. J. 7:180.

Jelkmann, W., Mikona, C., Turturo, C., Navarro, B., Rott, M. E., Menzel, W., Saldarelli, P., Minafra, A., and Martelli, G. P. 2012. Molecular characterization and taxonomy of Grapevine leafroll-associated virus 7. Arch. Virol. 157:359-362.

Jukes, T., and Cantor, C. 1969. Evolution of protein molecules. Pages 21-132 in: Mammalian Protein Metabolism. H. N. Munro, ed. Academic Press, New York.

Karasev, A. V., Boyko, V. P., Gowda, S., Nikolaeva, O. V., Hilf, M. E., Koonin, E. V., Niblett, C. L., Cline, K., Gumpf, D. J., Lee, R. F., Garnsey, S. M., Lewandowski, D. J., and Dawson, W. O. 1995. Complete sequence of the Citrus tristeza virus RNA genome. Virology 208:511-520.

Kiss, Z. A., Medina, V., and Falk, B. W. 2013. Crinivirus replication and host interactions. Front. Microbiol. 4:99. 
Klaassen, V. A., Boeshore, M. L., Koonin, E. V., Tian, T. Y., and Falk, B. W. 1995. Genome structure and phylogenetic analysis of Lettuce infectious yellows virus, a whitefly-transmitted, bipartite closterovirus. Virology 208: 99-110.

Kominek, P., Glasa, M., and Bryxiova, M. 2005. Analysis of the molecular variability of Grapevine leafroll-associated virus 1 reveals the presence of two distinct virus groups and their mixed occurrence in grapevines. Virus Genes 31:247-255.

Koonin, E. V., Dolja, V. V., and Morris, T. J. 1993. Evolution and taxonomy of positive-strand RNA viruses: implications of comparative analysis of amino acid sequences. Crit. Rev. Biochem. Mol. Biol. 28:375-430.

Kreuze, J. F., Savenkov, E. I., and Valkonen, J. P. 2002. Complete genome sequence and analyses of the subgenomic RNAs of Sweet potato chlorotic stunt virus reveal several new features for the genus Crinivirus. J. Virol. 76: 9260-9270.

Kumar, S., Stecher, G., and Tamura, K. 2016. MEGA7: Molecular Evolutionary Genetics Analysis version 7.0 for bigger datasets. Mol. Biol. Evol. 33:1870-1874

Le Maguet, J., Beuve, M., Herrbach, E., and Lemaire, O. 2012. Transmission of six ampeloviruses and two vitiviruses to grapevine by Phenacoccus aceris. Phytopathology 102:717-723.

Little, A., Fazeli, C. F., and Rezaian, M. A. 2001. Hypervariable genes in Grapevine leafroll associated virus 1. Virus Res. 80:109-116.

Lopez, C., Ayllon, M. A., Navas-Castillo, J., Guerri, J., Moreno, P., and Flores, R. 1998. Molecular variability of the $55^{\prime}$ - and $3^{\prime}$-terminal regions of Citrus tristeza virus RNA. Phytopathology 88:685-691.

Lu, R., Folimonov, A., Shintaku, M., Li, W. X., Falk, B. W., Dawson, W. O., and Ding, S. W. 2004. Three distinct suppressors of RNA silencing encoded by a 20-kb viral RNA genome. Proc. Natl. Acad. Sci. USA 101:15742-15747.

Maliogka, V. I., Dovas, C. I., and Katis, N. I. 2008. Evolutionary relationships of virus species belonging to a distinct lineage within the Ampelovirus genus. Virus Res. 135:125-135.

Maree, H. J., Almeida, R. P. P., Bester, R., Chooi, K. M., Cohen, D., Dolja, V. V., Fuchs, M. F., Golino, D. A., Jooste, A. E. C., Martelli, G. P., Naidu, R. A., Rowhani, A., Saldarelli, P., and Burger, J. T. 2013. Grapevine leafrollassociated virus 3. Front. Microbiol. 4:82.

Martelli, G., Abou Ghanem-Sabanadzovic, N., Agranovsky, A., Al Rwahnih, M., Dolja, V., Dovas, C., Fuchs, M., Gugerli, P., Hu, J., and Jelkmann, W. 2012. Taxonomic revision of the family Closteroviridae with special reference to the grapevine leafroll-associated members of the genus Ampelovirus and the putative species unassigned to the family. J. Plant Pathol. 94:7-19.

Martelli, G. P. 2014. Directory of virus and virus-like diseases of the grapevine and their agents. J. Plant Pathol. 96:1-136.

Naidu, R. A. 2017. Grapevine leafroll-associated virus 1. Pages 127-139 in: Grapevine Viruses: Molecular Biology, Diagnostics and Management. B. Meng, G. P. Martelli, D. Golino, and M. Fuchs, eds. Springer, Cham, Switzerland.

Naidu, R. A., Rowhani, A., Fuchs, M., Golino, D., and Martelli, G. P. 2014. Grapevine leafroll: A complex viral disease affecting a high-value fruit crop. Plant Dis. 98:1172-1185.

Napuli, A. J., Alzhanova, D. V., Doneanu, C. E., Barofsky, D. F., Koonin, E. V., and Dolja, V. V. 2003. The 64-kilodalton capsid protein homolog of Beet yellows virus is required for assembly of virion tails. J. Virol. 77: 2377-2384.

Navas-Castillo, J., Albiach-Marti, M. R., Gowda, S., Hilf, M. E., Garnsey, S. M., and Dawson, W. O. 1997. Kinetics of accumulation of citrus tristeza virus RNAs. Virology 228:92-97.

Peng, C. W., Peremyslov, V. V., Mushegian, A. R., Dawson, W. O., and Dolja, V. V. 2001. Functional specialization and evolution of leader proteinases in the family Closteroviridae. J. Virol. 75:12153-12160.

Peremyslov, V. V., and Dolja, V. V. 2002. Identification of the subgenomic mRNAs that encode 6-kDa movement protein and HSP70 homolog of Beet yellows virus. Virology 295:299-306.

Peremyslov, V. V., Andreev, I. A., Prokhnevsky, A. I., Duncan, G. H., Taliansky, M. E., and Dolja, V. V. 2004. Complex molecular architecture of beet yellows virus particles. Proc. Natl. Acad. Sci. USA 101:5030-5035.

Poojari, S., Alabi, O. J., and Naidu, R. A. 2013. Molecular characterization and impacts of a strain of Grapevine leafroll-associated virus 2 causing asymptomatic infection in a wine grape cultivar. Virol. J. 10:324.
Reed, J. C., Kasschau, K. D., Prokhnevsky, A. I., Gopinath, K., Pogue, G. P., Carrington, J. C., and Dolja, V. V. 2003. Suppressor of RNA silencing encoded by Beet yellows virus. Virology 306:203-209.

Robaglia, C., Durandtardif, M., Tronchet, M., Boudazin, G., Astiermanifacier, S., and Cassedelbart, F. 1989. Nucleotide sequence of Potato virus $Y$ (N-strain) genomic RNA. J. Gen. Virol. 70:935-947.

Rozanov, M. N., Koonin, E. V., and Gorbalenya, A. E. 1992. Conservation of the putative methyltransferase domain: A hallmark of the 'Sindbis-like' supergroup of positive-strand RNA viruses. J. Gen. Virol. 73:2129-2134.

Saitou, N., and Nei, M. 1987. The neighbor-joining method: A new method for reconstructing phylogenetic trees. Mol. Biol. Evol. 4:406-425.

Satyanarayana, T., Gowda, S., Ayllon, M. A., and Dawson, W. O. 2004. Closterovirus bipolar virion: evidence for initiation of assembly by minor coat protein and its restriction to the genomic RNA 5' region. Proc. Natl. Acad. Sci. USA 101:799-804.

Satyanarayana, T., Gowda, S., Ayllon, M. A., Albiach-Marti, M. R., and Dawson, W. O. 2002. Mutational analysis of the replication signals in the 3'-nontranslated region of Citrus tristeza virus. Virology 300:140-152.

Satyanarayana, T., Gowda, S., Mawassi, M., Albiach-Marti, M. R., Ayllon, M. A., Robertson, C., Garnsey, S. M., and Dawson, W. O. 2000. Closterovirus encoded HSP70 homolog and p61 in addition to both coat proteins function in efficient virion assembly. Virology 278:253-265.

Seddas, A., Haidar, M. M., Greif, C., Jacquet, C., Cloquemin, G., and Walter, B. 2000. Establishment of a relationship between grapevine leafroll closteroviruses 1 and 3 by use of monoclonal antibodies. Plant Pathol. 49:80-85.

Sievers, F., Wilm, A., Dineen, D., Gibson, T. J., Karplus, K., Li, W., Lopez, R., McWilliam, H., Remmert, M., and Söding, J. 2011. Fast, scalable generation of high-quality protein multiple sequence alignments using Clustal Omega. Mol. Syst. Biol. 7:539.

Simon-Loriere, E., and Holmes, E. C. 2013. Gene duplication is infrequent in the recent evolutionary history of RNA viruses. Mol. Biol. Evol. 30: 1263-1269.

Tatineni, S., Ziems, A. D., Wegulo, S. W., and French, R. C. 2009. Triticum mosaic virus: A distinct member of the family Potyviridae with an unusually long leader sequence. Phytopathology 99:943-950.

Thekke-Veetil, T., Aboughanem-Sabanadzovic, N., Keller, K. E., Martin, R. R., Sabanadzovic, S., and Tzanetakis, I. E. 2013. Molecular characterization and population structure of blackberry vein banding associated virus, new ampelovirus associated with yellow vein disease. Virus Res. 178: 234-240.

Thompson, J. D., Higgins, D. G., and Gibson, T. J. 1994. Clustal-W: Improving the sensitivity of progressive multiple sequence alignment through sequence weighting, position-specific gap penalties and weight matrix choice. Nucleic Acids Res. 22:4673-4680.

Tian, T. Y., Rubio, L., Yeh, H. H., Crawford, B., and Falk, B. W. 1999. Lettuce infectious yellows virus: In vitro acquisition analysis using partially purified virions and the whitefly Bemisia tabaci. J. Gen. Virol. 80:1111-1117.

Tsai, C. W., Rowhani, A., Golino, D. A., Daane, K. M., and Almeida, R. P. P. 2010. Mealybug transmission of grapevine leafroll viruses: An analysis of virus-vector specificity. Phytopathology 100:830-834.

Valverde, R. A., Nameth, S. T., and Jordan, R. L. 1990. Analysis of doublestranded-RNA for plant-virus diagnosis. Plant Dis. 74:255-258.

van den Born, E., Omelchenko, M. V., Bekkelund, A., Leihne, V., Koonin, E. V., Dolja, V. V., and Falnes, P. O. 2008. Viral AlkB proteins repair RNA damage by oxidative demethylation. Nucleic Acids Res. 36:5451-5461.

Vitushkina, M. V., Rogozin, I. B., Jelkmann, W., Koonin, E. V., and Agranovsky, A. A. 2007. Completion of the mapping of transcription start sites for the five-gene block subgenomic RNAs of Beet yellows Closterovirus and identification of putative subgenomic promoters. Virus Res. 128: 153-158.

Warren, C. E., and Murphy, J. F. 2003. The complete nucleotide sequence of Pepper mottle virus-Florida RNA. Arch. Virol. 148:189-197.

Yeh, H. H., Tian, T., Rubio, L., Crawford, B., and Falk, B. W. 2000. Asynchronous accumulation of Lettuce infectious yellows virus RNAs 1 and 2 and identification of an RNA 1 trans enhancer of RNA 2 accumulation. J. Virol. 74:5762-5768.

Zuker, M. 2003. Mfold web server for nucleic acid folding and hybridization prediction. Nucleic Acids Res. 31:3406-3415. 